\title{
Medisinsk fødselsregisters fødsel og senere vekst; noen observasjoner og refleksjoner fra hornet på veggen
}

\author{
Lorentz M. Irgens \\ Institutt for global helse og samfunnsmedisin, Universitetet i Bergen og \\ Medisinsk fødselsregister, Folkehelseinstituttet, Bergen \\ lorentz.irgens@uib.no
}

\section{SAMMENDRAG}

Da «Medisinsk melding om fødsel» ble etablert 1. januar 1967, var dette en melderutine som representerte noe nytt ikke bare $\mathrm{i}$ et norsk, men også $\mathrm{i}$ et internasjonalt perspektiv. Bakgrunnen var thalidomid-katastrofen som hadde rystet verden noen år tidligere. Men man hadde fra begynnelsen også et ønske om å skaffe et kunnskapsbasert grunnlag for fremtidens obstetrikk, neonatalogi og habilitering. Initiativet ble tatt av Helsedirektoratet. I den opprinnelige planen skulle fødselsmeldingene bearbeides og analyseres i Statistisk sentralbyrå (SSB), men det ble tidlig klart at dette ville sprenge de rammene SSB vanligvis arbeidet innenfor. SSB hadde heller ikke den medisinske kompetansen som var en forutsetning for en fullverdig utnyttelse av de innsamlede data. På denne tiden arbeidet dr.med. Tor Bjerkedal som medisinsk statistisk konsulent/forsker I i SSB. Da han i 1969 tiltrådte sitt professorat ved Institutt for hygiene og sosialmedisin (IHS), Universitetet i Bergen (UiB), brakte han MFRs første årganger av fødselsmeldinger med seg. I en avtale med helsedirektør Karl Evang ble Bjerkedal gitt i oppdrag å opprette og drive et register basert på meldingene. I informasjonsteknologiens barndom representerte denne oppgaven en pionerinnsats. Meldeskjemaets data ble punchet på et 80 karakterers hullkort som ble prosessert i UiBs store sentrale regnemaskin. Arbeidet ble utført av en liten, men entusiastisk gruppe medarbeidere, i det alt vesentlige finansiert ved hjelp av lokale UiB-ressurser. I tillegg gikk Norges almenvitenskapelige forskningsråd de første årene inn med midler, dels fordi ITaspektene ble sett på som innovative, dels fordi man forsto at de innsamlede data ville få stor forskningsmessig verdi. MFR ble raskt operativt med et system for overvåking av medfødte misdannelser og andre uønskede svangerskapsutfall. For å sikre oppfølgning av barn med behov for spesielle medisinske hjelpetiltak ble det startet prøveprosjekter med elektronisk registrering av data fra helsestasjonenes 1-års og 4årsundersøkelser samtidig som data fra vaksinasjonsprogrammet ble registrert, videreført i det nåværende SYSVAK. Etablering av alle driftsrutinene knyttet til MFR krevet omfattende innsats. Derfor ble den forskningsmessige utnyttelsen av de innsamlede data til å begynne med relativt beskjeden. Men etter hvert vokste det frem en omfattende vitenskapelig produksjon samtidig som antall ansatte økte; de første årene var 6-8 personer tilknyttet MFR mens i 2002 da MFR ble integrert som en avdeling i Folkehelseinstituttet var ca. 60 personer ansatt, herunder stipendiater. Virksomheten ved MFR kom til å bli avgjørende for at registerbasert epidemiologi ble et prioritert innsatsområde for Det medisinske fakultet ved UiB og for den videre etablering av helseregistre ved Folkehelseinstituttet i Bergen.

This is an open access article distributed under the Creative Commons Attribution Licence, which permits unrestricted use, distribution, and reproduction in any medium, provided the original work is properly cited.

\section{BAKGRUNN}

- hvorfor?

I 1957 kom legemiddelet Contergan for reseptfritt salg i Tyskland, mens det samme middelet under navnet Distaval kunne kjøpes på resept i Storbritannia fra 1958. Legemiddelet var thalidomid og ble benyttet som et sedativum og mot hyperemesis tidlig i svangerskapet samt en del andre tilstander. I oktober 1960 ble det presentert to kasuistikker vedrørende en meget påfallende reduksjonsdeformitet på et legemøte i Tyskland. I november 1961 lanserte den tyske pediateren Widukind Lenz hypotesen om at thalidomid var det aktuelle teratogen. Omtrent samtidig, og uavhengig av Lenz, ble det samme hevdet av William McBride i Australia. Det ble etter hvert klart at thalidomid var årsaken også til en rekke andre medfødte misdannelser, og rundt 10.000 barn kom til å bli ofre for denne legemiddelkatastofen. Det tok imidlertid mer enn 5 år før verden begynte å bli klar over hvilken katastrofe man sto overfor.

Mindre enn 6 år etter at mistanken om dette teratogenet ble fremsatt etablerte man «Medisinsk melding om fødsel» i Norge som kom til å bli historiens første landsomfattende medisinske fødselsregister. Den nye melderutinen hadde som en viktig begrunnelse at eventuelle nye teratogener skulle kunne bli oppdaget raskt og før en lignende katastrofe hadde utviklet seg.

\section{UNNFANGELSE}

\section{- hvem og når?}

Farskapet til MFR er av en viss interesse. På denne tiden var Fredrik Mellbye (1917-99) overlege i Helsedirektoratet. Mellbye introduserte den nye melderutinen på ikonisk for ikke å si profetisk vis (min kursivering): «Det vi må ta sikte på i årene fremover er å legge de praktiske forhold til rette for at det 
materialet som nå blir innsamlet og som kan suppleres, blir utnyttet i vitenskapelig og praktisk øyemed. På dette område, som innenfor all annen profylaktisk forebyggende medisinsk virksomhet, har vi i dag et klart behov for en vitenskapelig forskningsinstitusjon eller for en bevisst vitenskapelig aktivitet med formål å tilføre både helsemyndigheter og de praktiserende leger vel begrunnede og gjennomarbeidede forslag til hvordan det forebyggende helsearbeid bør drives, og å holde det arbeid som drives under kontinuerlig vitenskapelig observasjon». Videre presiserte Mellbye at «Staten må her tilrettelegge mulighetene for en vitenskapelig aktivitet med en bestemt målsetting som direkte kan komme det praktiske helsearbeid til hjelp. Den tid er forbi da vi på en rekke av de medisinske områder hvor samfunnet har påtatt seg et betydelig ansvar, kan basere oss på et skjønn alene».

Mellbye slo her til lyd for at det innsamlede materialet skulle gi grunnlag for:

- et kunnskapsbasert forebyggende helsearbeid med kontinuerlig kvalitetssikring,

- en statlig finansiert forskningsinstitusjon,

- kobling med andre datakilder.

Generelt var Mellbye langt forut for sin tid. Kunnskapsbasert forebyggende helsearbeid med kontinuerlig kvalitetssikring fikk vi etter hvert, men det tok lang tid. Kvalitetsindikatorene basert på MFR kom i begynnelsen av 1990-tallet. Den statlige finansieringen av en forskingsinstitusjon kom ikke $\mathrm{i}$ ordnede former før MFR ble integrert i Folkehelseinstituttet i 2002. Kobling med andre datakilder åpnet forskningsmuligheter som savnes i de fleste andre land, men ble motarbeidet i juridiske kretser.

Mer konkret fremhevet Mellbye tre hovedformål:

1. å analysere årsakene til sykdom og død blant svangre, til fosterdød og sykdom og død blant spedbarn.

2. å registrere barn med medfødte misdannelser for å sikre tidlig medisinsk behandling og observasjon.

3. å oppdage så raskt som mulig eventuelle stigninger i forekomsten av medfødte misdannelser slik at undersøkelser av årsak kan bli iverksatt.

Bakgrunn og formål tilkjennega betydelige ambisjoner. $\AA$ etablere en melderutine som skulle dekke et slikt informasjonsbehov i løpet av 4 år er intet mindre enn imponerende. En henvendelse til Helsedirektoratet om hvorvidt arkivmateriale kan belyse hvem som tok initiativ til melderutinen, når arbeidet ble påbegynt, hvordan saken ble behandlet, hvem som var den drivende kraft og i hvilken utstrekning fagfolk (obstetrikere, jordmødre, pediatere, epidemiologer) og jurister ble konsultert har imidlertid hittil ikke ført frem.

\section{FøDSEL}

- hvor?

Saken ble fremmet av Helsedirektoratet, men de innsamlede opplysningene skulle ikke behandles der; det skulle skje i Statistisk sentralbyrå (SSB). På denne tiden hadde SSB levert viktige bidrag til helsestatistikken i landet, først og fremst ved lederen av SSBs befolknings- og medisinalstatistikk, Julie E. Backer: Dødeligheten blant lungetuberkuløse (1937), Dødeligheten og dens årsaker i Norge 1856-1955 (1961), Ekteskap, fødsler og vandringer i Norge 1856-1960 (1965) og Dødeligheten blant spedbarn i Norge 19011963 (1966).

Bearbeidelsen av meldeskjemaene begynte derfor $\mathrm{i}$ 1967 i SSB der en ung ambisiøs lege deltok:

Norges leger 1996: «Gro Harlem Brundtland f.20/4 1939, statsminister.....kons Helsedirektoratet (medisinsk registrering av fødsel) 68-70...».

Men samtidig var også en noe eldre lege inne i bildet:

Norges leger 1996: «Tor Bjerkedal f.26/8 1926, professor dr.med....forsker I Statistisk Sentralbyrå 67-69...leder Med Fødselsreg fra 69 (sic.)...».

I mai 1969 tiltrådte Bjerkedal (1926-2015) et professorat $\mathrm{i}$ hygiene ved Universitetet $\mathrm{i}$ Bergen (UiB) medbringende de første årganger av meldeskjemaer samt avtale med helsedirektør Karl Evang (1902-81) om opprettelse og drift av MFR. Kildemateriale om hvordan denne ordningen kom i stand er begrenset, men den må ha bygget på en avtale mellom Helsedirektoratet og SSB inngått i desember 1969. Mellbyes visjoner var omfattende og forutsatte betydelig medisinsk, epidemiologisk, registerteknisk og medisinskstatistisk kompetanse, noe man ikke hadde i SSB. Det er derfor rimelig å anta at det etter hvert ble enighet om at den statlige forskningsinstitusjonen som Mellbye omtalte, ikke var SSB. Videre kan vi anta at Bjerkedal benyttet anledningen til å peke på sitt institutt i Bergen, IHS, som stedet. Og slik ble det.

Farskapet til MFR er fremdeles noe uklart, men Fredrik Mellbye må uten tvil ha vært delaktig innenfor Helsedirektoratets vegger. Tor Bjerkedal ble så en høyst avgjørende fødselshjelper ved IHS-UiB.

\section{NYFØDTPERIODEN}

\section{- hva og hvordan?}

Avtalen med Evang omfattet koding og databehandling av meldeskjemaene, produksjon av tabeller til publisering $\mathrm{i}$ den offisielle statistikk, etablering av et system for epidemiologisk overvåking av medfødte misdannelser og vitenskapelig bearbeidelse av materialet. I informasjonsteknologiens spedbarnsalder ble dette en formidabel pioneroppgave. Datakraft var tilgjengelig $\mathrm{i}$ UiBs store sentrale regnemaskin og databehandlingskompetanse ble hentet fra fakultetets EDB-seksjon som nylig var opprettet med betydelig støtte fra Norges almenvitenskapelige forskningsråd. Med anbefaling av Det medisinske fakultet vedtok Kollegiet at personale og utstyr skulle få plass i instituttets lokaler, og at UiB skulle foreta avlønning og regnskapsførsel.

For det første ordinære driftsår, 1971, støttet Sosial- 
departementet MFR med kr. 200.000,- (kr. 1.512.400,kpi justert pr. 2016). Av forarbeidene til MFR gikk det klart frem at departementet skulle være økonomisk ansvarlig for driften av MFR, men i praksis kom UiB til å spille en stadig viktigere rolle; i 1983 var bevilgningen økt til kr. 585.000,-, mens UiB dekket et underskudd på kr. 110.000,- og dertil et antall stillinger. Selv sett med kpi-justerte øyne er det uten videre klart at opprettelsen av MFR og driften de første årene var et ganske billig tiltak for helsevesenet; i dag ville man ikke kommet i mål med et ti-doblet kpi-justert beløp.

Arbeidet ble utført av en liten, men entusiastisk gruppe, visjonært ledet av Bjerkedal og med Leiv Bakketeig (1938-) og Egil Henrik Lehmann (1936-) som sentrale medarbeidere. Den nyfødte ble definert som observasjonsenhet og registeret ble opprettet med én elektronisk record per nyfødt. Hullkort på 80 karakterer avgrenset innholdet i recorden. MFR ble raskt operativt med et system for overvåking av medfødte misdannelser og andre uønskede svangerskapsutfall basert på cusum teknikk. Dermed var verdens første nasjonale fødselsregister en realitet.

For å sikre oppfølgning av barn med behov for spesielle medisinske hjelpetiltak ble det startet prøveprosjekter med elektronisk registrering av data fra helsestasjonenes 1-års og 4-års undersøkelser samtidig som data fra vaksinasjonsprogrammet ble registrert, videreført i det nåværende SYSVAK. På grunn av sterk motstand mot elektronisk registrering måtte helsestasjonsprosjektet avsluttes. Behovet for oppfølgningsdata var imidlertid bakgrunnen for arbeidet med å få i gang Den norske mor og barn-undersøkelsen (MoBa) på 1990-tallet og elektronisk registrering av data fra helsestasjon og skolehelsetjeneste er nå etablert som rutine i Bergen kommune.

Etableringen av alle driftsrutinene knyttet til MFR krevet omfattende innsats. Derfor ble den vitenskapelige utnyttelsen av materialet de første årene relativt beskjeden. Det ble publisert arbeider om svangerskapsutfall hos mødre med spesielle medisinske tilstander som epilepsi, astma, nevroser og tuberkulose, og det ble utarbeidet svangerskapsvarighet-spesifikke fødselsvekt-persentiler. En femårsrapport forelå i 1975.

\section{MFR SOM HITTEBARN}

- nok en gang «hvor»?

Allerede i 1976 fikk Bjerkedal et professorat i Oslo og Bakketeig forlot også Bergen. Mange mente at MFR burde flyttes til Oslo. Bjerkedal så dette som den naturlige løsningen, men også andre hadde lignende planer. Statens institutt for folkehelse (SIFF) hadde fått ny ledelse og instituttets interesseområde og mandat var nå rettet mer mot epidemiologi og ikke som tidligere mot mikrobiologi.

Avtalen mellom Helsedirektoratet og SSB ga hverken permanent økonomisk grunnlag eller personellmessig struktur for MFR. Heller ikke var organisatoriske forhold avklart. Behovet for formalisering hadde også bakgrunn i at MFR var blitt et nasjonalt informasjonssystem rettet mot forebyggende helsearbeid for mor og barn, men også med et datamateriale relevant for andre deler av det offentlige helsevesen. Allerede i 1971 ble det tatt initiativ fra IHS, UiB for å bringe MFR inn i mer ordnede former. (Bjerkedal var på denne tiden fremdeles trygt plassert $\mathrm{i}$ Bergen.) Dette ble innledningen til en lang rekke utredninger som ikke fikk noen konsekvenser for MFR:

- 1972, fra Helsedirektoratet via Sosialministeren: Forslag om «samordning» av Statens institutt for folkehelse (SIFF), Statens institutt for strålehygiene, Statens rettstoksikologiske institutt, Kreftregisteret og MFR.

- 1974-79, fra Helsedirektoratet: Samarbeidsdrøftinger mellom SIFF, Statens skjermbildefotografering, Kreftregisteret, Registeret for sinnslidende og MFR. Konklusjon (blant andre): "Alle nye registre burde legges til en etablert helseinstitusjon».

- 1975, fra Helsedirektoratet: «Problemnotat» om organisering og plassering av MFR: «MFR burde flyttes og inngå som en avdeling i SIFF».

- 1978, fra fylkeslegemøtet (januar) via Helsedirektoratet: Hurtigarbeidende utvalg (der Bjerkedal var medlem) (1. februar (sic.)): «MFR burde lokaliseres til Oslo og legges inn under SIFF».

- 1979-80, fra UiB til Helsedirektøren: Ønske om ny utredning av MFRs fremtidige organisasjon og drift.

- 1981, fra Helsedirektoratet: Utredning som konkluderte med at MFR burde knyttes til SIFF og deles $i$ to seksjoner, en i Oslo og en i Bergen.

Men så ble det endelig resultater: I 1983 kom utredningen fra Sosialdepartementet som la premissene for driften av MFR frem til 2002.

På dette tidspunktet hadde sentrale aktører ved UiB fått øynene opp for hvilket enormt forskningspotensial MFR innebar samtidig som man fant det rimelig å bli tilgodesett for de betydelige investeringene som UiB inntil da hadde stått for. En realitet som det var vanskelig å komme forbi var det tunge medisinske registerfaglige miljøet som var bygget opp ved IHS i form av teknisk registrering og analyse. Noe slikt hadde man ikke ved SIFF og å flytte miljøet til Oslo ble ansett som vanskelig.

\section{- nok en gang «hvordan»?}

Avtalen som ble inngått mellom SIFF og UiB innebar at Helsedirektoratet var eier av MFR og hadde det overordnede ansvar. SIFF var registeransvarlig, herunder med ansvar for at MFR skulle utvikles og drives på en forsvarlig og rasjonell måte; faglig, økonomisk, juridisk og administrativt. Avtalen innebar at sentrale funksjoner ble gitt som et langsiktig oppdrag til UiB. Funksjonene omfattet i praksis alle aspekter ved registerdriften inklusive den epidemiologiske overvåkingen. Forskning og utredningsarbeider kunne inngå som tidsbegrensede oppdrag.

Organisasjonsteoretikere ville muligens ikke ha levnet en slik modell de store sjanser for å lykkes. 
Likevel endte det med en suksesshistorie sett både fra Bergen og Oslo og dokumentert ved flere internasjonale evalueringer.

\section{UNGDOMSUTFORDRINGER}

- nok en gang «hvem»?

I dag vet vi hvordan det gikk, men som antydet, var situasjonen i en periode noe uklar. Fra 1976 til 1983 forelå det et interregnum. Formelt sett ledet Bjerkedal MFR fra Oslo, men i realiteten måtte mye av ledelsen skje i Bergen ved IHS. Som styrer ved instituttet, men også som overbevist registerepidemiolog falt det på meg å engasjere seg i driften av MFR og etter hvert også i de forhandlingene som førte til avtalen i 1983. Etter dette ledet jeg MFR frem til 2007.

- nytt skjema

Skjemaet som hadde vært benyttet siden 1967, hadde faglig bakgrunn i 1960-tallets medisin, og det var neppe blitt utformet med tanke på elektronisk databehandling. Hullkortteknologien som ble benyttet ved etableringen av registeret, ga grensene for omfanget av den elektroniske recorden. Etter 20 år tilsa både den medisinske og IT-messige utviklingen at MFRs registreringsskjema var modent for revisjon. På den annen side var ønsket om data som ville være sammenlignbare over tid, et argument for å utsette en revisjon.

Imidlertid, i begynnelsen av 1990-årene kunne ikke saken utsettes lenger og forberedelsen av et nytt skjema startet. Utvalg som representerte obstetrikk, pediatri og epidemiologi ble nedsatt, og det ble fremmet forslag om nye opplysninger man ønsket i skjemaet. Spesielt var det et stort savn at MFR ikke registrerte røkeopplysninger, men her møtte vi noen spesielle utfordringer. I Helsedirektoratet mente man at alle effektene av røking hos mor var kjent slik at dette var en unødvendig variabel. Vi tillot oss å betvile denne påstanden og gjorde også oppmerksom på at variabelen var en viktig effektforveksler som det måtte justeres for $\mathrm{i}$ epidemiologisk analyse. Med hjelp fra Georg Apenes i Datatilsynet fikk vi gjennomslag for røkeopplysninger $i$ det nye skjemaet, riktignok under forutsetning av mors samtykke.

Arbeidet med å forberede det nye skjemaet kom på denne måten til å ta lang tid og kreve mye ressurser, men stor var begeistringen da skjemaet omsider kunne taes i bruk 1/1 1999. Alle problemer var likevel ikke løst; det viste seg etter hvert at mange fødeavdelinger hadde tatt i bruk IT-utstyr til utfylling av skjemaene, levert av flere ulike systemleverandører. Dette var i utgangspunktet ikke klarert med MFR, og mye feil i programvaren kunne generere de merkeligste resultater, som for eksempel en epidemi av svangerskapsdiabetes ved et sykehus på Østlandet. Disse problemene førte til at vi allerede i 2000 startet prosjekteringen av direkte elektronisk melding til MFR som kom til å bli et ITmessig pionertiltak også i et internasjonalt perspektiv. Men selv i den elektroniske meldingen via Helsenettet måtte man operere med ulike systemleverandører for de ulike fødeavdelingene; at e-helse-Norge ikke kan enes om felles landsomfattende IT-systemer er uten tvil en av årsakene til den langsomme fremdriften på dette området.

\section{- juridisk hjemmel}

De første årene forløp ganske fredelig, juridisk sett. MFR ble opprettet med hjemmel i daværende lovverk: Legeloven (1927) og jordmorloven (1898). Få eller ingen så noe kontroversielt $\mathrm{i}$ virksomheten, men dette kom til å endre seg. Jurister våknet og deretter politikere. MFR ble angrepet fra to sider. Dels ble det hevdet at det anvendte lovgrunnlag var spinkelt. Det var det ikke så vanskelig å si seg enig i. Verre var det at selve det faglige grunnlag ble anfektet. Å registrere personidentifiserbare individdata med formål å bedre folkehelsen kunne ikke aksepteres med henblikk på de farer registreringen innebar for den enkelte og for samfunnet. Argumentene spente fra sikkerhetspolitiske gitt et demokratisk sammenbrudd til mer filosofiske bekymringer knyttet til kartlegging av risikofaktorer.

På slutten av 1990-tallet startet Helsedepartementet et viktig arbeid med sikte på å etablere et juridisk grunnlag for landets helseregistre og 18. mai 2001 ble helseregisterloven vedtatt av Stortinget. MFRforskriften ble så fastsatt ved kongelig resolusjon 21/12 samme år. Forskriften representerte i realiteten en juridisk konfirmasjon av en praksis tilbake til 1967 og innebar en betydelig støtte for oss som var ansvarlig for driften av MFR.

\section{- økonomiske bekymringer og reorganisering}

Frem mot årtusenskiftet fikk MFR stadig nye oppgaver blant annet med registrering av nemndbehandlede aborter og svangerskap etter kunstig befruktning. Etterspørselen etter informasjon fra MFR og analysefiler til forskning økte også i sterk grad. Dette medførte økte driftsutgifter og et økende antall medarbeidere. I 1999 hadde MFR et totalbudsjett på 8 millioner kroner hvorav 2,4 millioner ble dekket departementsmidler. Det resterende måtte dekkes av overhead på forvaltnings- og forskningsoppdrag samt av UiB. Driftsansvaret for MFR innebar dermed betydelige økonomiske bekymringer.

På denne tiden foretok departementet en gjennomgang av landets sentrale helseregistre. Det ble bestemt at alle registrene unntatt Kreftregisteret fra 2002 skulle integreres $\mathrm{i}$ og fullfinansieres gjennom det reorganiserte Folkehelseinstituttet. Dette løste et alvorlig problem. Samtidig ble det bestemt at MFR fremdeles skulle lokaliseres til Bergen, og det ble inngått en samarbeidsavtale med UiB om utnyttelsen av MFR i epidemiologisk forskning.

\section{HVA HAR MFR BETYDD I MEDISINSK FORVALTNING OG FORSKNING?}

De første årene var nok både de sentrale helsemyndighetene og helsepersonellet $\mathrm{i}$ landets sykehus noe usikre på hvordan MFR-data kunne utnyttes i helseforvaltningen. Mellbyes visjoner ble ikke straks omsatt i handling. Etter hvert som kvalitetssikring av medisinsk 
praksis ble et innsatsområde, forsto man verdien av MFR-data. For å synliggjøre dette, startet MFR på 1980-tallet utviklingen av kvalitetsindikatorer. Dette ble et nyttig verktøy, men utløste også frykt fordi det åpnet for sammenligning mellom fødeinstitusjoner. Selv sykehusspesifikke keisersnittsrater utløste emosjoner. Langt mer utfordrende var tall som viste store forskjeller mellom fødeavdelingene for rifter i fødselsveiene. Denne statistikken ble likevel utgangspunktet for en betydelig kvalitetshevende innsats. Med årene er klinisk kvalitetssikring blitt integrert $\mathrm{i}$ helsetjenesten, og MFRs institusjonsstatistikk er et meget egnet hjelpemiddel.

Men MFR spiller ikke bare en rolle i den daglige rutine. Også i krisesituasjoner har MFR-data vist sin verdi. Tsjernobylulykken i 1986 kom som et sjokk også på helsevesenet. Kreftfaren ble tidlig fokusert, men slike følger ville vise seg først etter mange år. Carcinogener er imidlertid også ofte teratogener, og i MFR innså vi raskt at registeret ville bli sentralt $i$ overvåkingen av helseskader i Norge; i MFR var det kun en latenstid på rundt 9 måneder. Et omfattende samarbeid med Statens strålevern som skaffet til veie meget detaljerte eksponeringsdata, ga som resultat at det ikke var noen økt forekomst av medfødte misdannelser etter denne ulykken. Det fremgikk også at omfanget av selvbestemte aborter ikke økte vesentlig. I Danmark, der sentrale helsemyndigheter hadde gitt langt mer alarmerende meldinger til befolkningen enn i Norge, økte denne abortraten sterkt.

Krybbedødsepidemien i Norge frem mot 1990 illustrerer MFRs rolle både $\mathrm{i}$ forvaltning og forskning. Det var lenge uklart at vi sto overfor en alvorlig økning $\mathrm{i}$ krybbedødsraten. Tallene fra SSBs dødsårsaksstatistikk viste en økning etter 1970, men dette ble avvist av rettsmedisinere som mente at økningen var et artefakt; økt oppmerksomhet rundt krybbedød førte til at klinikere benyttet denne diagnosen mer enn tidligere.

I MFR innså vi behovet for mer valide data og startet en epidemiologisk overvåking av krybbedød i samarbeid med SSB ved en manuell gjennomgang av alle postperinatale dødsmeldinger. Resultatet var en enda sterkere stigning i krybbedødsraten enn den som fremgikk av SSBs tall; mot slutten av 1980-tallet ble det registrert rundt 150 krybbedødsfall hvert år i Norge. Dødsmeldingene ble koblet mot MFRs fødselsmeldinger og ga grunnlag for omfattende epidemiologisk forskning. Særlig viktig var søskenflokkstudier som viste at gjentakelsesrisikoen for krybbedød var betydelig lavere enn det som var publisert tidligere; vesentlige arvelige etiologiske mekanismer var dermed lite sannsynlig.

Den koblede databasen ga også grunnlag for en nasjonal registerbasert tilfelle-kontrollstudie som, med tilsvarende datagrunnlag, ble utvidet til en nordisk og en europeisk studie. Her ble den sterke effekten av mageleie påvist på samme måte som $\mathrm{i}$ andre studier blant annet i Nederland og New Zealand. MFR dokumenterte deretter halveringen av krybbedødsraten fra 1989 til 1990 samtidig som forekomsten av mageleie ble halvert. I samarbeid med Landsforeningen til støtte for krybbedød evaluerte MFR effekten av en informasjonskampanje som ledd i kampen mot krybbedød. I dag dør færre enn 20 barn årlig av krybbedød i Norge.

Etter hvert ble MFR en tung epidemiologisk forskningsinstitusjon med et stort antall publikasjoner innenfor obstetriske og pediatriske emner. Dels har arbeidene vært forankret i MFR, dels har de blitt til i omfattende samarbeid med eksterne institusjoner. Etter hvert kom sentrale helsemyndigheter på banen med større oppdrag. Medfødte misdannelser var naturlig nok tidlig et viktig innsatsområde; her er nå også avansert genetisk metodologi utviklet og tatt i bruk. Mye forskning er knyttet til svangerskapsforgiftning og dens betydning for langtidsoverlevelse. Holdepunkter for genetisk bakgrunn er belyst i søskenflokkstudier. I de senere årene er sammenhenger mellom reproduksjon og fertilitet på den ene siden og langtidsoverlevelse på den annen blitt et sentralt forskningsfelt.

I flere evalueringer av norsk forskning i regi av Forskningsrådet og med internasjonale paneler er forskningen med utgangspunkt i MFR blitt bedømt som eksellent. MFR har bidratt sterkt til at registerbasert epidemiologisk forskning er blitt et prioritert innsatsområde ved UiB, og at Folkehelseinsituttet har lagt ytterligere sentrale helseregistre til registermiljøet i Bergen. Samarbeidet om Den norske mor og barnundersøkelsen har ført til en tilsvarende orientering av forskningen ved Folkehelseinsituttet.

Det har vært hevdet at sentrale helseregistre ikke bør være tilknyttet sterke forskningsmiljøer. At andre miljøer derved skulle få hindret adgang til registerdata har vært et argument. Å unngå slike uheldige forhold har stått sentralt i driften av MFR. Høy datakvalitet er nødvendig $i$ ethvert sentralt helseregister og sikres $i$ interaksjon med et nært tilknyttet forskningsmiljø som føler ansvar for registeret. Et slikt miljø vil også gi verdifulle råd til eksterne brukere med tanke på bruksområde for de enkelte registervariablene og deres begrensninger.

\section{KONKLUSJON}

Når vi ser på MFR 50 år etter at grunnstenen ble lagt, kan det kan neppe være tvil om at den visjonære Fredrik Mellbye og den ikke mindre visjonære Tor Bjerkedal har fått sine ideer og ønsker realisert innenfor medisinsk forvaltning så vel som forskning. 